\title{
Neuroethics and Spanish Literary Responses to "la crisis"
}

\author{
La neuroética y la respuesta literaria española a la crisis
}

\section{Resumen:}

El ensayo trata la posibilidad de cambiar la ética social a través del discurso del humanismo. Se subraya la base genética del comportamiento del ser humano, y la influencia que el medio ambiente puede tener sobre esto. Tomando como punto de partida la narrativa, y específicamente dos novelas españolas contemporáneos, se concluye que la narrativa ejerce una función de suma importancia en el desarrollo social, pero que dicha función es más allá del control del individuo artista, y que la ética es ex post facto, o sea producida por la narrativa, y no al revés.

Palabras clave: Narrativa, La ética y la genética, discurso social, humanismo, la crisis, literatura española.

\begin{abstract}
:
This essay treats the possibility of changing ethical behavior through the influence of humanistic discourse. The focus herein is on the genetic base of human behavior, and the influence the environment has upon it. Taking narrative as a point of departure, specifically two contemporary Spanish novels, the paper concludes that narrative exercises an determining role in social development, but a role that is beyond the conscious control of the individual. Furthermore, ethics seem to be an $e x$ post facto product of narrative, rather than the other way round.
\end{abstract}

Keywords: Narrative, ethics and genetics, social discourse, humanism, crisis, Spanish literature.

\section{Can the humanities make us more humane?}

Earlier this summer, in June of 2012 to be specific, I attended a conference at the Ateneo in Madrid. The theme of the conference was the relations between the sciences and the humanities in this, Spain's Year of Neuroculture. One speaker in particular caught my attention with his fervent insistence that the world would be a better place if only the scientists in it were given a strong dose of humanities. It certainly appeared it would be better for him at least, as his company was in the business of bringing doses of the humanities to the offices of local businesses. 
Specifically, they performed small theatrical productions on site that illustrated the correct responses to what otherwise would have appeared to be moral and ethical dilemmas in the business of business. On this theory, the proper dosage would convert corporate buccaneers into socially responsible citizens, who would henceforth design plowshares instead of swords, or something along those lines, you get the picture. Now, while I understand that his evaluation of the success of this program was anecdotal and, just perhaps, not the most objective one could hope for given his commercial interests, this did not rule out the possibility that he might be right.

Since my favorite pastime while listening to conference speakers is to prove them wrong-only in my head, of course, open warfare is in bad taste and doesn't advance your career-I started thinking about the history of support for the arts and humanities. Even for someone with as poor a memory as I, it soon became apparent that the rich and powerful have historically been the patrons of the arts, and open warfare with the Borgias, a Chinese emperor, the Russian Orthodox Church, or the Ford Foundation was also bad for your career, maybe very bad. But has this support translated into a better world, and if so is this transformation linked to neurological changes?

\section{Can society change our genetic nature?}

It is worth noting that the influence of the dominant social strata has produced recent genetic changes in our species, so socially induced neurological change is indeed possible. Following the advent of agriculture, some 11, 000 years ago, humans begin to show evidence of domestication. Farming led to the accumulation of wealth, hence to elites, who used their power to control aggression among their peasants. In vast segments of the new populations supported by agriculture, aggression among the lower classes was counterproductive to the accumulation of wealth by their owners. Through harsh authoritarian rule, humans were selected for domestication. Those who chose to die on their feet rather than live on their knees were accommodated or, as the Japanese saying has it, the nails that stood up were hammered down.

Indeed, in all domesticated animals, including humans beginning around 10,000 years ago, we see a reduction in brain size and skull size (a reduction of about 10 percent compared to Europeans from 20,000 years ago), changes in hair or coat color, smaller teeth, lower levels of aggression, and a willingness to submit to authority (Cochran and Harpending, 2009: 94). This pacification of the agricultural majority is reflected in the longitudinal data on human violence. There has been a hundredfold decline in homicide rates in European societies since the Middle Ages, from 100 per 
100,000 per annum to a current 1 per 100,000 per annum (Daly and Wilson, 1988: 48). The homicide rates in pre-state societies vary, with 10 to 60 percent of the men dying at the hands of another man (Daly and Wilson, 1988: 51; Keeley, 1996: 76). A typical tribal society loses about 0.5 percent of its population in combat every year. Had this same death rate been suffered by the rest of the population during the twentieth century, war deaths would have totaled two billion people instead of the 150-300 million that actually occurred (Keeley, 1996: 83). Among the Yanomamo of Brazil, one of the last remaining hunter-gatherer groups, about 30 percent of adult males die from aggression over the course of their lifetimes (the figure is 59 percent for the Jivaros of Ecuador and Peru) (Chagnon, 1992: 116). Comparatively, this same rate holds for chimpanzees, our hominoid cousins (96-99 percent of their DNA sequence corresponds exactly to our own, Chimpanzee Consortium, 2005: 77), who also practice constant warfare (Mitani, Watts, and Muller, 2002: 18). Among the Yanomamo, those who kill and survive have 3 times as many children as those who do not kill, while amongst chimpanzees 36 percent of all conceptions fall to the alpha chimp (Chagnon, 1992: 121; Constable, y otros, 2001: 1282).

But if humans have truly become less aggressive when it comes to killing each other, have they become less aggressive when it comes to other areas of social belligerence? If it is no longer ethical to take your neighbor's life, is it now any less ethical to use social power and influence to take his livelihood? In his book The Better Angels of our Nature: Why Violence has Declined (2011), Steven Pinker attributes the decline of violence over the last 10,000 years to cultural phenomena which he calls variously the Pacification Process, the Civilizing Process, the Humanitarian Revolution, the Rights Revolution, the Long Peace, the New Peace and so on. Essentially he traces the development of ever larger states, with farther reaching political and economic interests, which produced civilizations better suited to non-violence and able to enforce this state of affairs. He leaves open the question of the neurological background which makes these cultural changes possible. The issue he does not address directly is that of the propensity of humans to put aside their self-serving, aggressive tendencies, in order to cooperate for the general good. In fact, many authors point to the cultural forces behind the widening circle of peace, but offer no explication as to why humans should be susceptible to these cultural forces in the first place.

\subsection{Do we have selfish or altruistic genes?}

This question is, however, dealt with in recent work by Martin Nowak, Carina Tarnita, and Edward O. Wilson. The problem, first studied by Robert Trivers, has always been to explain altruism, since individual genetic selection, on its own, would not sustain a genetic adaptation for altruism. Selfish individuals would always out- reproduce, hence have more inclusive fitness, than altruistic individuals. 
But recent work has proven that natural selection occurs at both the individual and the group level, in what is called multi-level selection. Wilson explains:

\begin{abstract}
An iron rule exists in genetic evolution. It is that selfish individuals beat altruistic individuals, while groups of altruists beat groups of selfish individuals. Each member of a society possesses genes whose products are targeted by individual selection and genes targeted by group selection. Each individual is linked to a network of other group members. Its own survival and reproductive capacity are dependent in part on its interaction with others in the network.... what counts is the hereditary propensity to form myriad alliances, favors, exchanges of information, and betrayals that make up daily life in the network. (Wilson, 2012: 243).
\end{abstract}

Wilson goes on to highlight some of the neurological mechanisms that support this behavior and punish cheaters, explaining «In the brain, the administration of "altruistic punishment" lights up the bilateral anterior insula, a center of the brain also activated by pain, anger, and disgust» (Wilson, 2012: 251). In The Neuroscience of Fair Play (2007), Donald Pfaff shows how fear impulses from the amygdala can be suppressed by circuits in the anterior cingulate cortex and the insula, which enable ethical behavioral choices rather than simple reaction. It would seem, then, that the constant battle between cooperation and betrayal is a product of geneculture co-evolution. We are predisposed to be both selfish and altruistic, but not entirely constrained in either direction. So I return to my original question, which is what impact can a humanizing discourse have on these counterbalanced ethical decisions. To whom do I owe my allegiance, to self, group, family, tribe, class, race, or any of the other myriad entities seeking my loyalty and commitment?

\title{
3. Can literature make selfish people altruistic? Carlos Ruiz Zafón and Eduardo Mendoza
}

«A world of disorderly notions, picked out of books, crowded into his imagination»

Miguel de Cervantes_Don Quixote

Still wondering, I returned from the conference to Valencia, where I spent the next three months hearing about la crisis everyday on the morning news. The crisis referred to here is that part of the current global economic crisis affecting Spain, and it was, fundamentally, what my friend at the Ateneo was referring to as well. Essentially, the issue was one of selfish interests versus the common good, of the power of money, or perhaps better, greed, to corrupt cooperative civil action. In 
addition to listening to and reading the news, I spent the afternoons reading the latest commentary on the society that produced it by a couple of Spain's more influential humanists, at least in terms of their popularity with the general public, namely Carlos Ruiz Zafón and Eduardo Mendoza. Could, or did, their humanistic discourse tilt the balance of ethical decisions from local to global, or at least national, allegiance?

Now there are certainly those who would argue that what people say on Twitter or Facebook is far more influential and representative of the general flow of public discourse, and maybe that's true, but the two authors I have mentioned do sell a lot of books to a middlebrow crowd, are consulted as to their opinions on television and in various newspapers, and even have some resonance in university academic circles, where articles are written about them and their books are taught in the occasional literature class. So they do seem to represent one measure of public discourse regarding the state of the country and, I would argue, they constitute a fairly influential facet of that discourse in that they both reflect and help to construct public opinion.

In Ruiz Zafón's book, Eljuego del ángel (2008), the protagonist is a writer named David Martín. In the novel, part of a trilogy set around the time of the Spanish Civil War, Martín rises by dint of his innate artistic ability from an impoverished childhood, in which he is abandoned by his mother and abused by his criminal/ junkie father, to become a successful writer. Two people are instrumental in saving him from life in the underclasses, an aristocratic aficionado of the arts and would-be writer, Pedro Vidal, and the kindly and wise owner of a small but discriminating bookstore, Sempere senior of Sempere e Hijos. It is Sempere who, by way of not so subtle foreshadowing, gives Martín his first book, Charles Dickens' Great Expectations. Unfortunately, thereafter small businessman Sempere is able to offer only moral support as he is unceasingly on the verge of bankruptcy, while the rich aristocrat Vidal trades jobs and influence for a debt of guilty gratitude and compliance.

Though Martín is blessed with rare artistic talent, he is continuously at the mercy of commercial publishing interests, and so taken advantage of by them. His initial writing assignment, a serial novel entitled Los misterios de Barcelona, is for the newspaper La Voz de la Industria, which first capitalizes on his ability for slave wages then fires him. His next writing job is with a medium size publisher, Barrido y Escobillas, who were looking for «sangre fresca que exprimir y explotar» (Ruiz, 2012: 70). In exchange for writing two hundred pages a month, under a pseudonym, of a series called La ciudad de los malditos, «tramadas de intrigas, asesinatos de alta sociedad, horrors sin cuento en los bajos fondos, amores ilícitos entre cruel hacendados de mandíbulo firme y damiselas de inconfesables anhelos, y toda suerte de retorcidas sagas familiars con trasfondos más espesos y turbios 
que las aguas del Puerto» (Ruiz, 2012: 71), he is paid a small wage and receives no author's rights.

The work is a success and attracts the attention of a larger international publisher. Martín is offered a small fortune to work for this Paris firm, Éditions de la Lumière. The editor is Andreas Corelli and, as becomes clear in the novel, Corelli is the devil incarnate. In exchange for filthy lucre the artist has, literally, signed a deal with the devil. He is commissioned to create a work following the devil's own design. And if that weren't enough, the love of his life, Cristina Sagnier, uses guilt and his repressed love of her to force him to anonymously write a novel that his old patron, Pedro Vidal, can claim as his own. Yet another deal with the devil. Because of all this Martín's life follows the paths of the characters in La ciudad de los malditos, and so the author of noir detective books comes to live the life of his fictional characters.

But what is it that the devil wants? According to Corelli, Martín must create a new religion, as apparently the devil is less than satisfied with his place in the current one. But the essential point is the role of narrative in the new enterprise. Corelli explains, that «una religión viene a ser un código moral que se expresa mediante leyendas, mitos o cualquier tipo de artefacto literario a fin de establecer un sistema de creencias, valores y normas con los que regular una cultura o una sociedad» (Ruiz, 2012: 186). And if the emphasis on narrative weren't sufficiently apparent in the first explanation, Corelli makes sure Martín gets the connection between narration and belief: «Todo es un cuento Martín. Lo que creemos, lo que conocemos, lo que recordamos e incluso lo que soñamos. Todo es un cuento, una narración, una secuencia de sucesos y personajes que comunican un contenido emocional. Un acto de fe es un acto de aceptación, una aceptación de una historia que se nos cuenta. Sólo aceptamos como verdadero aquello que puede ser narrado» (187).

A bit later on in the novel Corelli explains why narrative has such a potent effect: «el acto de creer en mitos o ideologías o leyendas sobrenaturales, es consecuencia de la biología....La fe es una respuesta instintiva a aspectos de la existencia que no podemos explicar de otro modo....es simple y pura biología» (Ruiz, 2012: 258). And finally, Corelli argues for our instinctive reaction to art as the motor that drives our lives, «Por eso necesito algo más poderoso que una simple exposición retórica. Necesito la fuerza del arte, de la puesta en escena. La letra de la canción es lo que creemos entender, pero lo que nos hace creerla o no es la música» (Ruiz, 2012: 261). Essentially, then, the devil is arguing that the drive to create and believe stories, and to act upon these beliefs, is an adaptation via natural selection, and one that he can control.

\section{Narrative is an adaptation that has evolved by natural selection.}


God made Man because He loves stories Ellie Wiesel-The Gates of the Forest

To say that narrative is an adaptation that has evolved by natural selection is a statement that, for some, might require a bit of evidence. I therefore ask the reader's indulgence while I briefly play the role of the devil's advocate in an attempt to demonstrate the genetic foundations of narrative. As we progress from infants to adults in a given society or societies, we produce various narrative systems - everything from the clothes we wear, the food we eat, the music we listen to, and the cars we drive tell our stories- but language is one of the first systems we develop, and it is a primordial measure of narrative, so we can start with it. As is well known, language is universal across human societies. Every neurologically normal person learns the language, or languages, of his or her society. Indeed, humans learn the exact dialect of not only their society but of their socio-economic class and age group. All of these are systematic and rule-governed, and none are simple or «primitive» (McWhorter, 2002: 94). All human languages conform to a universal design or universal grammar as Chomsky would have it, and all children pass through a universal series of stages during language acquisition (Baker, 2001: 114; Pinker, 1994: 86). Even their errors are systematic, and don't come from their parents' input, but rather from the aforementioned universal grammar all humans share (Crain, 1992: 75). And as Derek Bickerton's work on Creole languages in Hawaii has shown, children thrown together without a common language will invent a new one, and it will have all the grammatical features of our shared universal grammar (Bickerton, 1990: 39). A similar result was observed in the case of deaf children in Nicaragua, who on their own developed a complex sign language to use amongst themselves (Dessalles, 2007: 70-73). Additionally, language and general intelligence are doubly dissociable in neurological and genetic disorders such as aphasias and Specific Language Impairment syndrome. In these cases, very intelligent people can have serious problems in speaking and understanding, while severely mentally retarded people can have no difficulties in these areas (Siegal y et al, 2001: 298 ).

Furthermore, as Steven Pinker points out, recent advances in molecular and population genetics demonstrate that language shows evidence of a history of selection. He cites studies that have identified a gene on Chromosome 7, FOXP2, which is associated with Specific Language Impairment Syndrome, and whose normal allele «plays a causal role in the development of the brain circuitry underlying language and speech, rather than merely disrupting that circuitry when mutated" (Pinker, 2002: 34). He goes on to affirm there are many genes for language, and discusses other loci, distinct from FOXP2, as well as detailing quantitative data which demonstrate a history of genetic selection based on statistical patterns of 
variation among genes (Krietman, 2000: 542; Przeworski y et al, 2000: 301). Finally, Enard y et al report in Nature that the FOXP2 gene has been a target of direct selection in humans for «the last 200,000 years of human history» (Enard, 2002: 3), and Dean Hamer chronicles a statistically significant relation between the VMAT2 gene and spirituality in humans. Humans are genetically disposed «to believe in things they cannot see, smell, taste, hear, or touch» (Hamer, 2005: 6), precisely the kinds of things narratives ask them to believe.

In addition to language, and a number of other psychological and emotional propensities, narrative too is innate in humans. First of all, we know it develops spontaneously in the individual. In the first five years of life children develop language and narrative, which enables them to arrive at a conscious awareness of both self and the external socio-cultural world. At the age of about nine months (Tomasello, 1995: 452) the infant becomes aware of social signals of which he or she was previously ignorant. These first stirrings of intersubjectivity open the door for language acquisition. From the age of 1 to 2 years language ability and cognitive functions improve, but the child still lacks temporal perspective and multiple world views (Nelson, 1999: 262). At about one year they can remember only brief sequences of events (Bauer and Mandler, 1990: 21), but as language ability grows, narratives of the cultural and social milieu become accessible and the child begins to insert himself into this larger story. At three years they can relate a number of familiar events in reliable sequence (Nelson and Grundel, 1981: 144). Preschoolers, between the ages of two and a half to five years, gradually learn to produce rudimentary narratives, but still have difficulty incorporating both temporal perspectives and essential cultural knowledge, and also have trouble distinguishing between self and others (Nelson, 2003: 22). Gradually, through a growing awareness of the larger socio-cultural narrative, the child learns to differentiate himself from others by defining his own role in this larger social story. Self-consciousness is defined in relation to others, who are defined narratologically. By the age of six a child has fully developed the narrative mechanisms which will define his ideas of self, other, and all things real and imagined for the rest of his life.

To explain the innateness of narrative, many have argued that there is a narrative proclivity hard-wired into the human mind, waiting only to be triggered by exposure to the social world in infancy and then exploding when language becomes available (Bruener, 1990: 160). Because narratives universally appear as the same social formsmyths of origin, explanatory myths, definitions of group identity, moral and ethical guidelines, and so on-a universal narratological grammar appears to be innate in humans. As with their native language, children inevitably grow into the existing cultural narratives and myths of their native society, just as humans have done for thousands of generations (Hendriks-Jansen, 1996: 46). So as individuals we appear to have inherited a uniquely human ability for narrative, a complex socio-biological adaptation (a trait 
whose genetic basis was shaped by natural selection) evolved by way of natural selection over the past eight million years or so. But why did this come about?

\subsection{The adaptive use of narrative: The Tsembaga, and other examples}

As always when talking about stories, another story can serve to illustrate the first. In a book that was hugely influential in the United States in the 1970s and 80s, prompting as it did the sustainable ecology movement, Pigs for the Ancestors (1968), Roy A. Rappaport analyzes the ten-to twenty-year ritual cycle of the Tsembaga Maring of colonial New Guinea. The Tsembaga cultural narrative is based on supposed debts owed to the ancestors, these represented by two sets of spirits, called the Red Spirits and the Spirits of Rot. In the Maring view, in order to appease the spirits of the dead ancestors the living must engage in a cycle of ritualized warfare, animal husbandry, agriculture, marriage, reproduction, and various other social rituals and taboos, all regulated by the kaiko, a ritual pig sacrifice to the ancestral guardians. The net effect of this cycle is to maintain a sustainable balance between and within the human population and the natural environment through time. The taboos on sowing certain plants too often or too closely together prevent crop diseases. Sexual taboos limit population increase, as does the ritualized warfare. Taboos on eating certain animals at certain times conserve the fauna of the area. Ritual exchange and marriage between groups facilitate trade and mitigate against genetic maladies. In the final analysis, the Tsembaga do all the right things for all the wrong reasons, because as far as they are concerned they are dealing with spiritual concerns, not ecological matters. They have co-evolved, along with their natural environment, an ecosocial system that, barring drastic change, could last indefinitely, and it is based on an irrational cosmology (unless of course the Red Spirits actually exist).

The primary contribution of Rappaport's book is to show that myth and ritual are functional elements in maintaining both intraand extrasocial relations (or ecological balance). That is, the stories societies tell themselves at the manifest level enable human populations to optimize their adaptations to the environment and to maintain undegraded local and regional ecosystems, and at the same time maintain their system of social stratification intact. Importantly, this happens in spite of the fact that they are unaware of this process, and so have quite different readings of their own myths and rituals. The stories vary from culture to culture, but their ultimate function does not. For Rappaport, narrative mediates the relation between society and nature.

The standard criticisms of Rappaport's analysis are first that there are no isolated ecosystems today and that all humans participate in a global system. One can counter by observing that not only primitive but also modern myths, the ratio-scientific mode included, fall into the pattern Rappaport exposed, and so in Modernity the global rather than local or regional use of narratives is simply a quantitative differ- 
ence. In this sense, scientific narrative is functionally indistinguishable from mythical narrative. Secondly, it has been argued that either culture is sui generis, autonomous and explicable in its own terms, an idealist position, or epiphenomenal, explicable completely in terms of nature, a materialist position. Following Rappaport, I will argue that there is a relation of feedback between the two via human narration, and so the two — society and Nature — are separate but dialectically linked by how they influence each other. Social narratives mediate this relation. Finally, it has been objected that natural selection operates on the individual rather than on the ecosystem, society, or culture. There is today a growing body of evidence supporting group selection over individual selection (Bloom, 2000: 3-13), especially the aforementioned work of Martin Nowak, Carina Tarnita, and Edward O. Wilson. Their research has refuted the Hamilton inequality (1964), $(r b>c)$, which held that natural selection occurred only at the level of the individual, and that any altruistic behavior reflected the degree of relatedness of the actor to the recipient of said behavior, the so-called «inclusive fitness". Novak and company showed that natural selection takes place at both the individual and the group level, what they call multilevel selection. This is because selfish individuals compete better against altruistic individuals, but altruistic groups compete better against selfish groups. In order for these groups to cooperate against other groups they need a driving mechanism, and this appears to be religiously inspired narrative, or better, narrative grounded in faith, since in modernity that faith is not always in religion.

This also serves to answer another question, that of the very existence of religion, which is hard to explain unless we take all religions at their word when it comes to the existence of their gods. If, however, the gods do not exist, then religious people the world over systematically err in their judgments about the world. Normally, living organisms get the world right, as it is often crucial to their survival that they do so. Yet humans universally develop non-empirically supported religious beliefs, even in scientifically advanced societies, that encourage costly behavior (Godfrey-Smith, 1996: 143). Participants routinely subject themselves to fatigue, injury, and bodily harm, and in extreme cases willingly participate in suicide bombings, genital mutilation, and voluntary celibacy. All this, and much more, is done in the name of supernatural gods with supernatural powers that neither the believers nor anyone else has ever seen or directly experienced. Indeed, the poverty of supernatural stimulus is nearly complete, which begs the question: Why do the followers of any religion not only believe in an unseen spirit world, but also devote a large measure of their wealth, time, and energy to this super-nature? The devil in Ruiz Zafón's book argues it is to get people to do what they cannot be rationally convinced to do. And since the process is innate and universal-children universally and automatically develop religious beliefs even in atheistic homes (Bulbulia, 2007: 625) — it must be an adaptation by natural selection. 
Examples of narratological adaptation abound. As Claude Levi-Strauss detailed in The Elementary Structures of Kinship, early human societies separated into moieties, groups narratologically identified with various opposing forces of the natural world - earth and sky, night and day, etc-whose members were forbidden to marry each other, but rather had to pick mates from other moieties, thus avoiding inbreeding. The Montagnais-Laskapi of the Labrador plateau north of Quebec utilize divination by burnt animal bones to direct their hunts. This rite of divination introduces a randomizing element into their hunting pattern, assuring that they will not always be successful. This apparently irrational magic serves the very rational function of preventing over-harvesting of game animals, and so functions to maintain a balance between the human and animal population (Moore, 1969: 17-43). We can also cite the "superstitions" of the peasant community on Sardinia, one of the effects of which is to prevent pregnant women, who are particularly susceptible, from venturing into the malarious lowlands (Brown, 1997: 241). Many more examples could be given, we've not even mentioned Marvin Harris or E.E. Evans-Pritchard, but the best evidence is to point to the sheer number of societies, all through the course of human history, that have co-evolved long-standing relations with their natural environment by means of "irrational" beliefs in myth and magic. Indeed, the only examples of the "rational" type have occurred with the rise of industrial society over the last few hundred years, and their continued existence is far from guaranteed, and their belief systems far from rational.

\subsection{Who controls narrative?}

«Where they burn books they will ultimately burn people». Heinrich Heine-Almansor (burned, along with many other books, by the Nazis on the night of May 10,

The interesting aspect of this process is that it seems to be beyond the control of any individual. What Zafón appears to be saying in El juego del ángel is that artistic discourse is controlled by the ruling elite, in this case the international publishing company whose power and money have eliminated local alternatives. You can write what you want, but to get it published you have to toe the line of the powers that be. The rich and powerful elites thus control public discourse, and so control our motivating faiths and beliefs, thus ultimately our actions. On this view the search for the truth is like a dark detective mystery, one detective/writer against the world, and the world usually wins. Therefore, to get back to my doubts from the Ateneo about whether the world would be a better place if only the scientists in it were given a strong dose of humanities, it seems the answer from at least one leading Spanish 
humanist is that this can never happen under our current system. Those in charge are not going to cede control over public discourse to a competitor, though they are certainly willing to decorate their enterprises with the trappings of a kinder, gentler humanism. And so, essentially, Spanish artists and writers are not responsible for the current crisis or any other, given that the choice is make a deal with the devil or lose everything, as happened to Martín in the novel when he tried to renege on his Faustian agreement.

But before we draw too grave a conclusion from but one example, let's take a look at a recent contribution from another hugely successful contemporary Spanish writer, the aforementioned Eduardo Mendoza. Mendoza's 2010 novel, which won the Premio Planeta in 2010, is titled Riña de gatos: Madrid 1936. The book deals with the visit to Madrid of an English art expert, Anthony Whitelands, to verify the authenticity of a painting, supposedly a previously unknown work by Velázquez. The painting in question is owned by an aristocratic family with ties to the family of Miguel Primo de Rivera, former Spanish dictator from 1923 to 1930. The former dictator's son, José Antonio Primo de Rivera, plays an active role in the novel, in that he is the leader of the Falangist party, and the funds derived from the sale of the painting are destined to buy arms for his revolutionary group.

What the novel actually deals with is the confusion that reigns amongst politicians, lovers, intellectuals, spies, and everyone else involved in the plot of the book. For example, Whitelands is leaving England partly to get away from an illicit affair he is having with the wife of an old university friend. He can't decide if he loves her, if she loves him, and whether he should end it or not. At the beginning of the novel he is leaving to end it, but at the end of the book he is returning to England possibly to restart the relation. In the meantime he has had three affairs in Madrid, two with minors, and none of the three women are certain as to their feelings for him, or of his for them. He himself is constantly changing his own opinion on the matters.

He was recruited for the mission by one Pedro Teacher, a semi-reputable art merchant and sometime German spy, or perhaps double or even triple agent, no one knows for sure. Whitelands does know that the man who introduced him to one of his teenage lovers later saved his life. He thought the man a good citizen, but at the end of the novel we find out the individual in question, Higinio Zamora Zamorano, was a British spy who also worked for the Russian secret service, the NKVD. The NKVD had another agent as well, the mysterious Kolia, who may have secretly been anybody, perhaps even José Antonio Primo de Rivera, but we never do find out who he really was.

The spies and the politicians who run them are all interested in either having the Velázquez authenticated or in having it declared a forgery, in function of whether they want the Falange to get the money for arms and so start serious trouble or 
not. The politicians, however, are as misguided in their reading of world events as everyone else is. At the end of the novel Lord Bumblebee, head of the British secret service, tells Whitelands:

No se preocupe por su amigo Primo; no le pasará nada. El fascism es un incordio, pero no es un problema. El problema viene de Rusia. Tarde o temprano Inglaterra habrá de aliarse con Alemania para hacerse frente a la amenaza comunista....Su majestad [Eduardo VIII] así lo entiende y no oculta sus simpatías por Hitler. Hitler no es un demócrata cabal, es cierto, pero la política no permite hacer distingos. (Mendoza, 2010: 421).

And while this prognostication could not have been more wrong for the Second World War, it proved correct, at least in part, for the Cold War.

In order to get the assessment they want of the painting, the British Secret Service brings in Whitelands's mortal adversary, Edwin Garrigaw, head of the National Gallery in London, and the other world-renowned expert on Velázquez. Garrigaw, naturally, sees the painting as a forgery, while Whitelands considers it authentic, although their official views go back and forth depending on whether the British want to support the fascists or the communists at a given moment. Nevertheless, the struggle to determine the truth of art exemplifies the struggles to find the truth in the other aspects of the novel, from love to politics to identity. The ambiguity inherent in the discourse of art symbolizes, literally, the ambiguity in how both people and events are read and misread in the novel. One example of this is a painting by Titian called The Death of Actaeon (1560-70). The subject of the painting follows Ovid's account in the «Metamorphoses». In revenge for surprising her as she bathed naked in the woods, the goddess Diana transformed Actaeon into a stag and his own hounds attacked and killed him. A copy of the painting hangs in the entryway of the house of the Duke of Igualada, the owner of the disputed Velázquez. It is the first painting Whitelands sees on his trip to Madrid. He immediately comments on the ambiguity in the painting, «Tiziano representa la escena de un modo incoherente» (32), and then gives various possible interpretations, without settling on any particular one. This because he has just arrived in Spain and the painting refers to, among other things, the situation in Spain.

Another character, the leader of the ruling party, Manuel Azaña, also weighs in. Referring to the painting, Azaña says «Tiziano elige un punto medio en el decurso de la fábula: lo escencial ya ha ocurrido o está por ocurrir... El momento en que la falta ya ha sido cometido y la flecha ha sido lanzado. Lo demás es cuestión de tiempo: el desenlace es inevitable» (Mendoza, 2010:337). As in the case of Whitelands, this assessment reflects the view in Spain just prior to the outbreak of the civil war. It is also worth noting that the traditional interpretation of the painting 
is that of the hunter who becomes the hunted, an ironic development portrayed through the ages, the latest example being Llewelyn Moss (Josh Brolin) and Anton Chigurh (Javier Bardem) in the Coen brothers' film No Country for Old Men (2007). And this interpretation, too, has resonance in the upcoming Spanish civil war. Later, Whitelands returns to the home of the Duke of Igualada, views the painting again, and concludes that in the painting Titian portrays «...el castigo irracional y desmesurado impuesto por una diosa cautiva de su simbología y de su poder sin trabas. Diana dominaba la escena, como las fuerzas despiadadas que se abaten sobre los hombres: como la enfermedad, como la Guerra, como las pasiones malsanas» (Mendoza, 2010:345). And these last are, of course, the same forces that are beating down upon Whitelands and Spain.

As in political discourse, emotional discourse, and espionage, pinning down one fixed truth, in the interplay of symbols and messages in art, becomes a subjective enterprise. On this view, the artist escapes responsibility for the actions of others by nature of the very ambiguity inherent in the work of art. It is, however, worth noting that the various antagonists - lovers, spies, and politicians - do cooperate to extricate Whitelands from his various predicaments, saving his life in the process, and return him to England safe and sound. The implication here is that public discourse, in the person of Whitelands, who ties all the different subplots together, can engender cooperation amongst adversarial positions. Human society is a combination of altruism and egoism, with both being difficult to recognize correctly. Is the Velázquez a fake or authentic? It depends.

With reference now to our original question, that of the possible pacifying effects of the discourse of the humanities, at least two points emerge from Ruiz Zafón's and Mendoza's subtexts. The first is that the effects of public discourse are unpredictable, given the ambiguities inherent in the messages and symbols of art, literature, politics, religion, love, and so on. The second, which follows from the first, is that artists bear no responsibility for social conditions, given that they have no control over how their messages will be interpreted. We can't tell the real painting from the fake, true love from false, a double agent from a triple agent, nor an accurate political prognostication from a self-justifying confabulation. Apparently, no one is actually responsible for the actions of society, since no one knows the truth, and it appears to matter little in any event. And besides, the rich devils that run the huge corporations, and publishing houses, are too powerful to control even if we knew what was best. And if we think logic and reason can save us, we need think again. As Kurt Gödel and Bertrand Russell have shown, logic itself is inherently self-contradictory, and Freud demonstrated the rational mind was seldom in charge anyway. The Frankfnrt School has argued convincingly that the fetishization of reason has produced a modern myth that simply replaced the pre-enlightenment superstitions from which it 
sought to free us, becoming a negative dialectic in the process by going from controlling nature to controlling society. Max Weber made a similar case, arguing that Reason was simply an instrument in the hands of those wishing to gain control. Nietzsche was equally dubious of transcendental truths, writing "facts are precisely what there is not, only interpretations» (Nietzsche, 1968:267). And modern psychology has demonstrated that we deceive ourselves constantly and don't even realize it.

There does appear to be, however, some sort of universal grammar involved in social discourse. Returning to Rappaport's work with the Tsembaga, we can note that their religious discourse made them do the right thing for the wrong reasons, and history is full of similar examples. Ethical considerations seem initially to be constrained by social discourse, rather than the other way round. Some discourses gain traction, while the rest do not, and then they become naturalized. From faith in religion to «the invisible hidden hand of the market», the Five Year plan of the Politburo, the scientific method, or the word of the Prophet, questionable assumptions have brought fairly decent results. Humans have grown and prospered, gone from worshipping the moon to walking on it, and all the while guided by irrational narratives. If the positions of Ruiz Zafón and Mendoza appear apologist, they may still be quite defensible. If the dominant discourse of a society is indeed irrational, and beyond the control of anyone, much like Saussure's langne, then artists who fail to speak out against the current, or in fact any crisis, are off the hook. Ruiz Zafón's character Martín sacrificed all in fighting the devil, with very little to show for it. Mendoza's Velázquez couldn't have been more cooperative with Felipe IV, and was richly rewarded, while his argumentative Golden Age contemporary Lope was forced to choose between death and exile to Valencia, and was then punished with what he felt to be the worst of the two possibilities.

\section{By way of conclusion}

It is undeniable, then, that there is something in humans, a narrative propensity, an adaptation that has evolved through natural selection over thousands of generations, which enables humans to cooperate in groups in order to persevere through changing environments, be they climactic, social, or economic, ice ages, wars, or crisis. These genetic predispositions are triggered by environmental stimuli, and so are susceptible to discovery, explanation and, yes, manipulation, and we have already seen the beginnings of a genetic engineering which appears capable of massive control. We can at present use genetic screening to avoid diseases, genetic therapy to cure disease, cosmetic genetics to choose eye and hair color, pigmentation, and body build. Many mental and emotional conditions, such as I.Q. are hereditary, 
and so in principal there is nothing to stop us from selecting for these through the so-called designer genes (Potter, 2010:162-75), a lá Andrew Niccole in his 2007 film GATTACA. At some point they must surely be understood, and then the real question of the relative power and influence of the humanities and the sciences will come to the fore. It would seem that at some point a neurocultural approach will provide either the ultimate breakthrough or the ultimate breakdown. And when it comes we'll not be able to decide which it is.

\section{Works Cited}

Baker, M. (2001): The Atoms of Language, New York, Basic Books.

Bauer, P.J. and J.M Mandler. (1990): «Remembering What Happened Next: Very

Young Children's Recall of Event Sequences», in R. FIvush and J.A. Hudson (ed.) (1990): Knowing and Remembering in Young Children. New York, Cambridge UP, pp. 9-29.

Bickerton, D. (1990): Language and Species, Chicago, Chicago UP.

BLoom, Harry. (2000): Global Brain: The Evolution of Mass Mind from the Big Bang to the $21^{\text {st }}$ Century. New York, Wiley.

Bowler, J.M., et al. (1970): «Pleistocene Human Remains from Australia», World Archaeology, 2, pp. 39-60.

Brown, P. J. (1997): «Malaria, Miseria, and Underpopulation in Sardinia: The 'Malaria Blocks Development' Cultural Model», Medical Anthropology, 17, pp. 239-54.

Bruener, J.S. (1990): Acts of Meaning. Cambridge, MA, Harvard UP.

Bulbulia, J. A. (2007): «The Evolution of Religion» in R. Dunbar and L. BarretT (ed.) (2007): The Oxford Handbook of Evolutionary Psychology, Oxford, Oxford UP, pp. 621-35.

Chagnon, N. A. (1992): Yanomamo: The Last Days of Eden, New York, Harcourt Brace.

Chimpanzee Sequencing and Analysis Consortium. (2005): «Initial Sequence of the Chimpanzee Genome and Comparison with the Human Genome», Nature 436, pp. 69-87.

Chomsky, N. (1995): The Minimalist Program. Cambridge, MA, Мiт P.

Cochran, G., and H. Harpending. (2009): The 10,000 Year Explosion: How Civilization Accelerated Human Evolution, New York, Basic Books.

Constable, J. L., y et al. (2001): «Noninvasive Paternity Assignment in Gombe Chimpanzees», Molecular Ecology 10, pp. 1279-1300.

Crain, W. (1992): Theories of Development: Concepts and Applications. New York, Prentice Hal.

Daly, M., and M. WiLson. (1988): Homicide. New York, Gruyter. 
Dessalles, J-L. (2007): Why We Talk: The Evolutionary Origins of Language, Trans. J. Grieve. New York, Oxford UP.

De Saussure, F. (1987): Curso de lingüistica general, Madrid, Alianza.

Ehrenreich, B. (1997): Blood Rites: The Origins and History of the Passions of War, New York, Henry Holt.

ENARD, W., y et al. (2002): «Molecular Evolution of FOXP2, a Gene Involved in Speech and Language», Nature 418, pp. 869-72.

Godfrey-Smith, P. (1996): Complexity and the Function of Mind in Nature, Cambridge, Cambridge UP.

Hamer, D. (2005): The God Gene: How Faith is Hardwired into Our Genes, New York, Anchor.

Hendriks-Jansen, H. (1996): Catching Ourselves in the Act: Situated Activity, Interactive Emergence, Evolution, and Human Though, Cambridge, MA, MIT P.

Keeley, L. H. (1996): War before Civilization: The Myth of the Peaceful Savage, New York, Oxford UP.

Kreitman, M. (2000): «Methods to Detect Selection in Populations with Applications to the Human», Annual Review of Genomics and Human Genetics, pp. 539-59.

Lévi-Strauss, C. (1969): The Elementary Structures of Kinship, Trans. J. Harle Bell, J. Richard von Sturmer, and R. Needham. Boston, Beacon.

McWhorter, J. (2002): The Power of Babel: A Natural History of Language, New York, W.H. FreEMAN.

Mendoza, E. (2010): Riña de gatos; Madrid 1936, Barcelona, Planeta.

Mitani, J. C., D. P. Watts. and M. N. Muller. (2002): «Recent Developments in the Study of Wild Chimpanzee Behavion», Evolutionary Anthropology 11, pp. 9-25.

Moore, O. K. (1969): «Divination - A New Perspective", en Andrew P. VAYDA, (ed.) (1969): Environment and Cultural Behavior: Ecological Studies in Cultural Anthropology, Garden City N.Y., Natural History P, pp. 121-9.

Nelson, K. (2003): «The Emergence of Consciousness of Self », en Gary D. Fireman, T. E. Mcvay, jr., and O. J. Flanagan (ed.) (2003): Narrative and Consciousness: Literature, Psychology, and the Brain,), Oxford, Oxford UP, pp. 17-36.

- (1999): «Memory and Belief Development», en D. Schacter and E. ScArry (ed.) (1999): Memory, Brain, and Belief, Cambridge, MA, Harvard UP, pp. 259-89.

Nelson, K., and J. Gruendel. (1981): «Generalized Event Representations: Basic Building Blocks of Cognitive Development», en M. LAMB and A. BROWN (ed.) (1981): Advances in Developmental Psychology 1, pp. 131-58.

Nietzsche, F. (1968): The Will to Power, New York, Vintage.

Nowak, M. A., C. E. Tarnita, and E. O. Wilson. (2010): «The Evolution of Eusociality», Nature 466, pp. 1057-62.

PInker, Steven. (2012): The Better Angels of our Nature: Why Violence Has Declined, New York, Viking. 
- (2002): The Blank Slate: The Modern Denial of Human Nature, New York, Penguin.

- (1994): The Language Instinct: How the Mind Creates Language, New York, Harper Collins.

Potter, S. (2010): Designer Genes: How the Forces of Natural Selection are About to Be Replaced by Human Selection, New York, Random House.

Przeworski, M., R.R. Hudsom, y A. Di Rienzo. (2000): «Adjusting the Focus on Human Variations», Trends in Genetics 16, pp. 296-302.

Rappaport, R. A. (1969): Pigs for the Ancestors, New Haven, Yale Paperbacks.

Ruíz Zafón, C. (2012). El juego del ángel. Barcelona, Planeta.

Siegal, M., R. VARLEY, and S.C. WANT. (2001): «Minds over Grammar: Reasoning in Aphasia and Development», Trends in Cognitive Sciences 5, pp. 296-301.

Smith, D. L. (2007): The Most Dangerous Animal: Human Nature and the Origins of War, New York, St Martin's.

Tomasello, M. (1995): «Understanding the Self as Social agent», en P. Rochat, (ed.) (1995): The Self in Infancy: Theory and Research, Amsterdam, Elsevier, pp. 449-60.

Wilson, E. O. (2012): The Social Conquest of Earth, New York, W.W. Norton.

Articulo recibido: 05/10/2012

Solicitud de revisión: 09/11/2012

Artículo aceptado: 12/04/2013 